\title{
ハードウェアベース安全装置を搭載した膝関節用アシストスーツの開発 （機構の提案・設計）
}

杉山 将史 ${ }^{* 1}$, 池田 啓祐 ${ }^{* 2}$, 金田 翼*2, 甲斐 義弘 ${ }^{* 3}$, 富塚 誠義*4

\section{Development of a knee joint assist suit with hardware-based safety devices (Proposal and design of the assist suit)}

\author{
Masahito SUGIYAMA $^{* 1}$, Keisuke IKEDA ${ }^{* 2}$, Tsubasa KANEDA ${ }^{* 2}$, \\ Yoshihiro KAI ${ }^{* 3}$ and Masayoshi TOMIZUKA ${ }^{* 4}$ \\ ${ }^{{ }_{1}^{*},{ }^{*},{ }^{*} 3}$ Department of Mechanical Engineering, Tokai University \\ 4-1-1 Kitakaname, Hiratsuka-shi, Kanagawa 259-1292, Japan \\ ${ }^{*} 4$ Department of Mechanical Engineering, University of California, Berkeley \\ Berkeley, CA 94720 USA
}

Received: 22 June 2017; Revised: 14 August 2017; Accepted: 6 November 2017

\begin{abstract}
When developing rehabilitation assist suits, safety consideration for patients is crucial. Computer-aided control techniques can improve their safety. However, when the computer breaks down, the assist suit may be dangerous for the user because of its unintentional motion. Therefore, assist suits with hardware-based safety devices are desired to guarantee safety even when the computers do not operate properly. In this paper, we present a new rehabilitation assist suit equipped with a velocity-based safety device and a torque limiter. The assist suit assists a patient's knee joint. The velocity-based safety device switches off the assist suit's motor if it detects an unexpected high joint angular velocity. The torque limiter cuts off the torque transmission if it detects an unexpected high joint torque. These safety devices will work even when the computer breaks down, because they consist of only passive mechanical components without actuators, controllers, or batteries. Firstly, we describe the features of the assist suit with the safety devices. Secondly, we introduce the structure of the assist suit. Thirdly, we explain the structure and mechanism of the velocity-based safety device. Fourthly, we show the prototype assist suit that we have developed. Finally, we present experimental results to verify the effectiveness of the velocity-based safety device installed on the developed assist suit.
\end{abstract}

Keywords : Robot, Design, Mechanism, Rehabilitation assist suit, Mechanical safety device

\section{1. 緒言}

脳卒中をはじめとする中枢神経疾患などで歩行が困難になった患者の歩行訓練は，しばしば，患者の体重を 免荷する吊上げ装置やトレッドミルを用い，理学療法士が患者の脚の動きを手動でアシストしつつ実施されて いる(Westlake and Patten, 2009). 今後, 世界的に高齢化が進行し(United Nations Population Fund and HelpAge International, 2013)，歩行機能に障がいを持つ患者が増加すると，理学療法士の身体的負担が増加するだけでな く，患者の歩行訓練に十分な時間を掛けることも困難になると予想される．以上のようなことから，理学療法 士に代わり，患者の身体に装着し脚の動きをアシストするアシストスーツの開発が望まれてきている(長谷川, 山海, 2014) (Riener, 2012) (Zhang et al., 2012) (Cherelle et al., 2010). このような身体に装着し歩行訓練をサポート するアシストスーツにおいて，患者に対する安全性を確保することは極めて重要な課題になる.

コンピュータ制御技術を駆使してアシストスーツの安全性を向上させることは非常に重要である(Bae et al.,

No.17-00279 [DOI:10.1299/transjsme.17-00279], J-STAGE Advance Publication date : 15 November, 2017

*1 学生員, 東海大学大学院工学研究科（干259-1292 神奈川県平塚市北金目 4-1-1）

*2 東海大学工学部機械工学科

*3 正員, 東海大学工学部機械工学科

*4 正員，カリフォルニア大学バークレー校工学部機械工学科（Berkeley, CA 94720 USA）

E-mail of corresponding author: kai@tokai.ac.jp 
2011). しかし，コンピュータや電気式センサ等が故障し，アシストスーツの制御が不能となった場合でも患者 に対する安全性を確保する対策も重要と考えられる.

アシストスーツの制御が不能となった場合の安全対策として, 非常停止ボタンの使用や関節可動域リミッタ の使用が考えられる(Kawamoto et al., 2003) (Chen et al., 2007). しかし，非常時には患者や周囲の人がボタンを押 せない場合も考えられる. また, 関節可動域リミッタを使用寸る場合, リミッタによりアシストスーツが停止 するまでに, (i)患者の脚部が高速度で動かされる, (ii)患者の関節に高トルクが加えられてしまうといった問題 が考えられる.

本論文では，アシストスーツの安全性向上を目指し，ハードウェアベース安全装置（速度ベース安全装置・ 市販のトルクリミッタ）を搭載したアシストスーツ（具体例として膝関節用アシストスーツ）を提案する．本 アシストスーツは, 脳卒中をはじめとする中枢神経疾患や未梢神経損傷など(医療情報科学研究所, 2011)(園田, 2005)のため自力で膝関節を運動させることが困難な患者を対象とする. また，患者の体重を免荷する吊り上げ 装置, トレッドミルを併用して歩行訓練を行うことを想定している (図 1 参照)。速度ベース安全装置は, アシ ストスーツにより患者の膝関節が予め設定したレベル以上の速度で動かされた際，アシストスーツのモータの 電源を切る．また，トルクリミッタは，アシストスーツにより患者の膝関節に予妋諚したレベル以上のトル クが加えられた際, そのトルクを遮断する. 速度ベース安全装置・トルクリミッタともに, バネやダンパなど の受動的機械要素のみで構成されているので，アシストスーツの制御用コンピュータが故障した場合でも機能 する.

本稿では，まず，提案するアシストスーツの特徵について説明する. 次に，提案するアシストスーツの構造， 速度ベース安全装置の構造・メカニズムについて述べる. さらに, 実際に設計・開発したアシストスーツを示 す. 最後に, 本研究オリジナルの速度ベース安全装置が目的通り動作するか否かについて, 実験を行うことに より検証する.

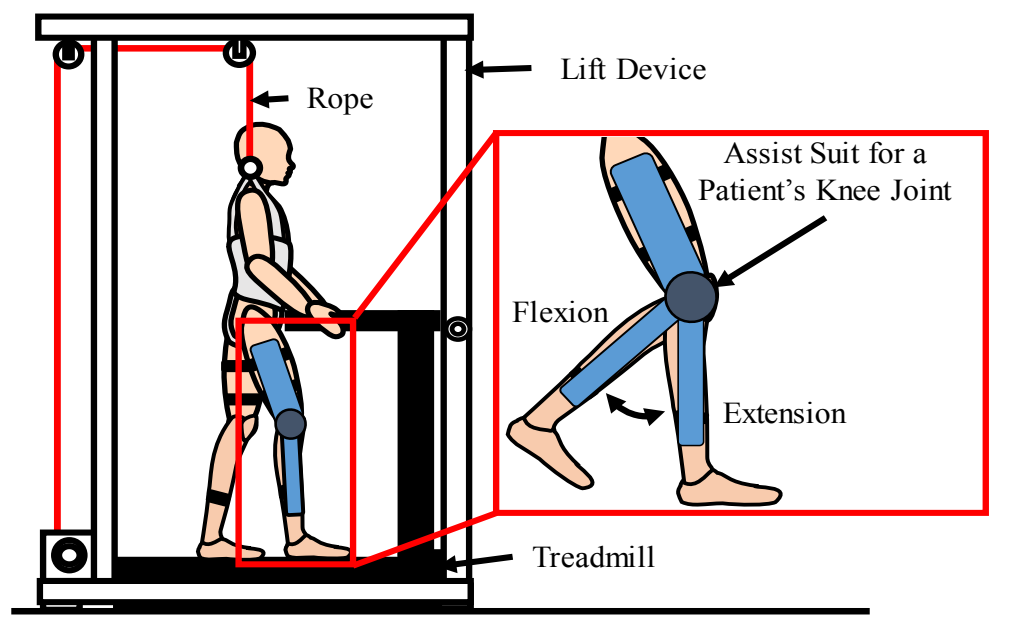

Fig. 1 Gait training using the assist suit for a patient's knee joint. The patient trains on the treadmill. The lift device provides the patient with partial body weight support and prevents the patient from falling down.

\section{2. 速度ベース安全装置・トルクリミッタを搭載したアシストスーツの特徴}

コンピュータの故障等によりアシストスーツの制御が不能となり予期せぬ高速度が発生すると, 図 2(a)に示 すように，患者の足部がトレッドミルの歩行路面に高速で衝突する危険性がある. また，予期せ如高トルクが 発生すると, 図 2(b)に示すように, 足部・下腿部の圧迫等の危険性がある. 本研究ではこれらの問題を解決す

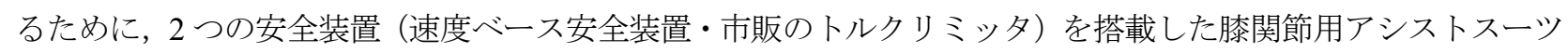
を提案する. 本アシストスーツの特徴を以下に示す.

(1)モータの角速度が予め設定した速度レベルを超過した場合, 速度ベース安全装置によりモータの電源が切ら れ, アシストスーツは停止する. 本研究では, 予め設定する速度レベルを“検知速度レベル”と呼ぶ. 
(2) 検知速度レベルは設定変更が可能である.

(3) モータの角速度が検知速度レベルを超過せず, モータのトルクが予め設定したトルクレベルを超過した場合, モータから患者脚部へのトルクの伝達がトルクリミッタにより遮断される. 本研究では, 予め設定するトルク レベルを“検知トルクレベル”と呼ぶ.

(4) 検知トルクレベルは設定変更が可能である.

上記特徴(1)により，「暴走したアシストスーツにより患者の脚部が予期せぬ高速度で動かされる」ことが避け られる. また, 特徴(2)により, 使用する各患者に応じて検知速度レベルを変更することができる. さらに, 特 徵(3)により,「暴走したアシストスーツにより患者の膝関節部へ予期せぬ高トルクが加えられる」ことが避け られる．特徵(4)により，使用する各患者に応じて検知トルクレベルを変更することができる.

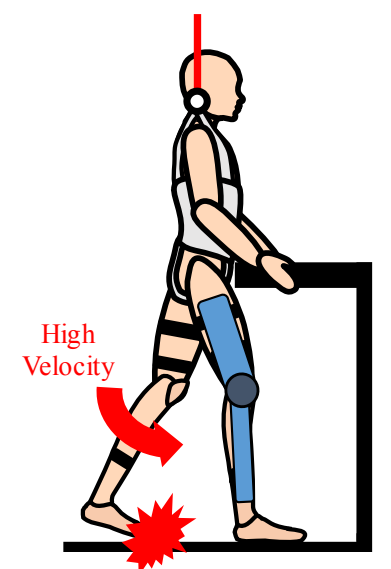

(a) High Velocity

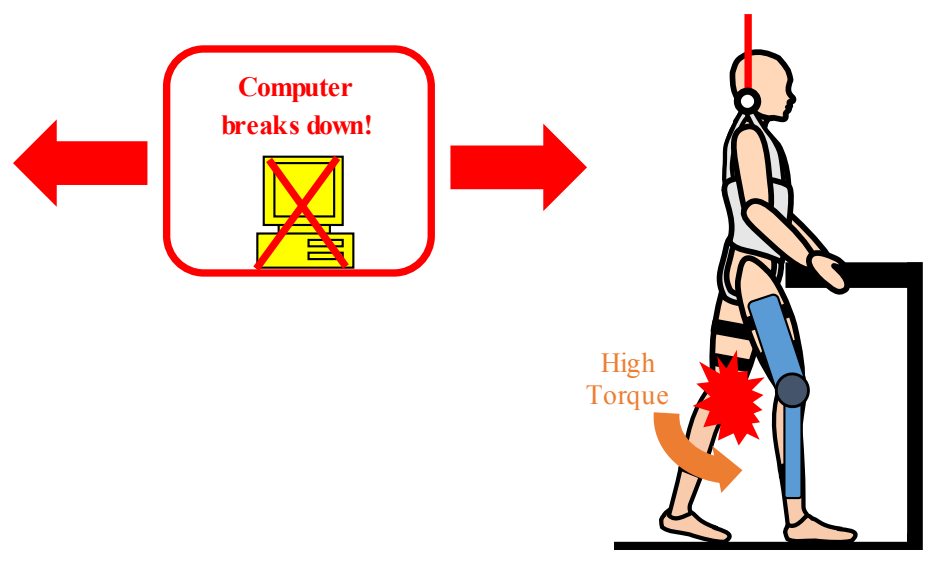

(b) High Torque

Fig. 2 Problems in the case of computer failure. When the assist suit's computer breaks down, (a) the assist suit may move a patient's leg at unexpected high velocities or (b) may exert unexpected high torques to the patient's joints.

\section{3. アシストスーツ}

本研究で提案するアシストスーツの概観図と分解図を図 3 に示寸. 本研究では，これまでに Kai が開発して いる患者を吊り上げて歩行訓練を行う患者吊り上げ装置(Kai，2013，同図参照) とトレッドミルを備えた歩行支 援システム等を併用し歩行リハビリテーションを行うことを想定している. これにより，アシストスーツの安 全装置が作動し患者の脚がフリーになった際の転倒を防止する.

\section{$3 \cdot 1$ アシストスーツの構造}

図 3 に示寸とおり, 本アシストスーツは患者の大腿部と下腿部にブレースで装着され, 患者の膝関節をアシ

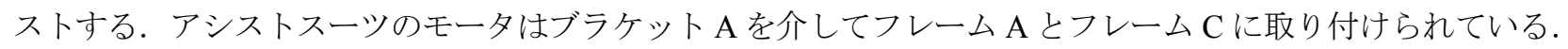
モータのトルクは, ギアヘッド (遊星歯車), カップリング, シャフト A, トルクリミッタ, シャフト B, トー ションバネ, シャフト $\mathrm{C}$, かさ歯車 $\mathrm{A}$, かさ歯車 $\mathrm{B}$, シャフト $\mathrm{D}$, フレーム $\mathrm{B}$ を介して患者の下腿部に伝達さ れる. シャフト D (患者の膝関節) の速度は, ギア $\mathrm{A}$ を介して速度ベース安全装置のギア B まで伝達される.

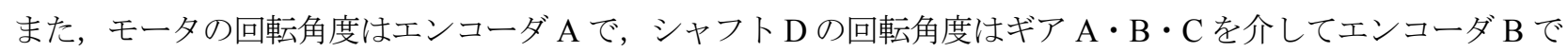
計測される.

アシストスーツに搭載したトーションバネは，(i)患者の膝関節の動きとアシストスーツの動きのずれを許容 するためだけでなく, (ii)トルクセンサとして使用するために用いている(Kong et al., 2012). すなわち, トーショ ンバネの両端の位置をエンコーダ A と B で計測し, その角度差から患者の膝関節へ加えられるトルクを計測す ることを想定し使用している.

さらに, 安全装置が作動した際のアシストスーツのバックドライブ性を高める（すなわち, 患者の膝関節を フリーにする）ため，動力伝達においてギアヘッド（遊星歯車）およびかさ歯車を使用している. 
Walking Support System

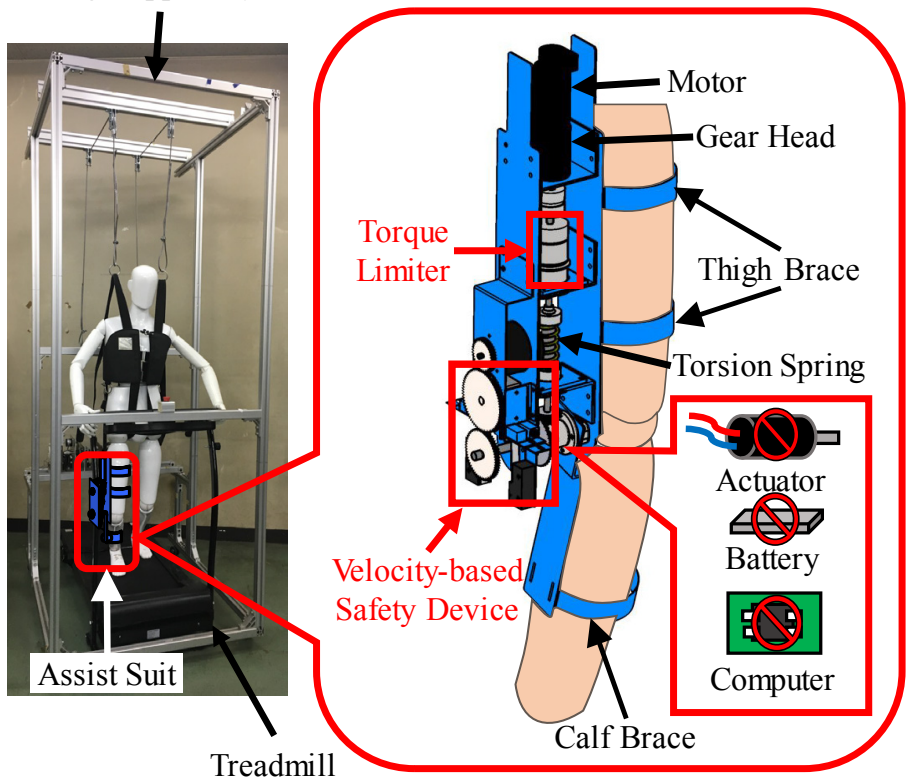

Treadmill

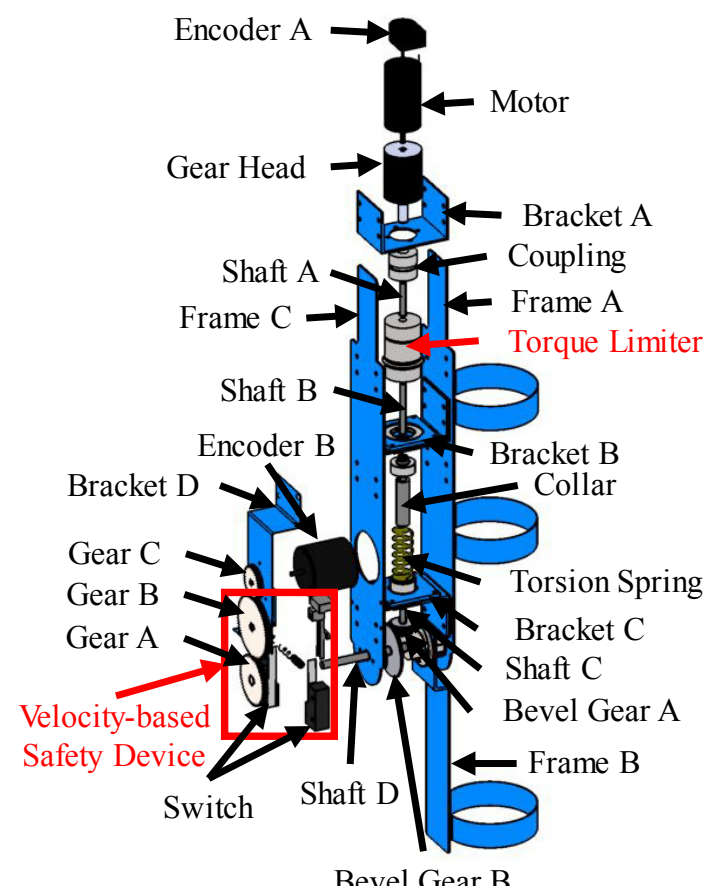

Bevel Gear B

Fig. 3 Assist suit with the velocity-based safety device and the torque limiter. The assist suit assists a patient's knee joint. The motor of the assist suit is attached to Frame A and Frame $\mathrm{C}$ via Bracket $\mathrm{A}$. The motor torque is transmitted to the calf brace via a gearhead, a coupling, Shaft A, a torque limiter, Shaft B, a torsion spring, Shaft C, Bevel Gear A, Bevel Gear B, Shaft D, and Frame B. Also, the rotation of the motor is transmitted to Gear B in the velocity-based safety device via Shaft D and Gear A.

\section{$3 \cdot 2$ 速度ベース安全装置}

\section{$3 \cdot 2 \cdot 1$ 構造}

速度ベース安全装置の概観図と分解図を図 4 に示す。 上述したとおり，シャフトD（患者の膝関節）の回転 はギア A を介してギア B に伝達される. ギア B はロータリーダンパに取付けられており，ロータリーダンパに モータからの回転が伝達される. ロータリーダンパはベアリングを介してブラケット Dに取付けられている. バーはロータリーダンパの出力軸に接続されており，バーには 2 本の引張バネが取付けられている. 引張バネ の両端は 2 本のピンで引張バネブラケットに取り付けられている. モータの電源を切るためのスイッチはスイ ッチブラケットに取り付けられている. スイッチブラケットは引張バネブラケットを介してブラケット Dに取 付けられている。 また，ブラケットDはフレーム $\mathrm{C}$ に取り付けられている.

\section{$3 \cdot 2 \cdot 2$ メカニズム}

速度ベース安全装置のメカニズムを図 5 に示す。ギア B が回転することにより，バーにはロータリーダンパ からギア B の角速度 $v$ に比例したダンピングトルクと引張バネによるスプリングトルクが作用する。ギア B 角速度が予め設定した角速度 $v_{\text {Detection }}$ （すなわち，検知速度レベル）以上で回転すると，バーに作用するダンピ ングトルクが，スプリングトルクに打ち勝ち，バーによりスイッチが押されモータの電源が切られる。また， シャフト D が逆方向に予め設定した角速度以上で回転した場合も同様に逆方向に設置したスイッチがバーによ り押され，モータの電源が切られる．なお，検知速度レベル $v_{\text {Detection }}$ は，スイッチの位置を変更することで調整 が可能である。

バーの重心位置がロータリーダンパの回転軸に一致し，バーの慣性モーメントが十分小さいと仮定する．ま た，バーの角速度 $\dot{\theta}$ が $v$ と比較して十分小さく，初張力 $F_{0}$ の 2 つの引張バネを自然長 $l$ からバネの最大たわみ の半分の長さ $a$ だけ伸ばした位置からバーに取り付けたとすると，バーの運動方程式は次式のようになる.

$$
r\left\{k(a+r \theta)+F_{0}\right\}-r\left\{k(a-r \theta)+F_{0}\right\}=c v
$$


ここで, $r$ は引張バネの取り付け位置からロータリーダンパの回転軸までの距離, $c$ はロータリーダンパの粘性 係数， $\theta$ はバーの回転角度変位， $k$ は引張バネのバネ定数である. 式(1)より, 検知速度レベルは以下の式を用 いて設定することができる.

$$
v_{\text {Detection }}=\left(2 k r^{2} \theta_{p}+\tau_{p}\right) / c
$$

ただし， $\theta_{p}$ はスイッチを切る時のバーの角度， $\tau_{p}$ はバーがスイッチを切るために必要なトルクである.

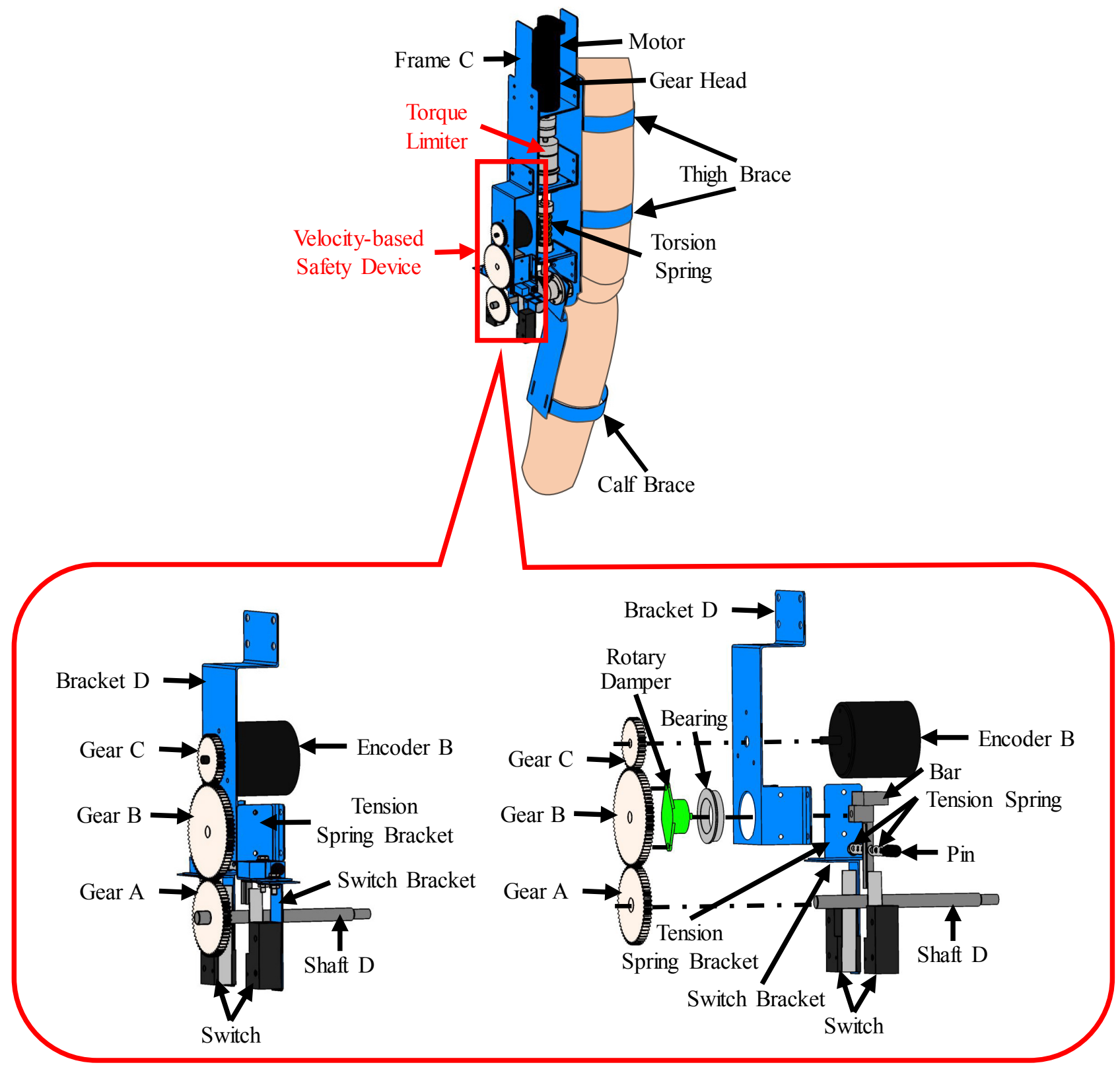

Fig. 4 Structure of the velocity-based safety device. The velocity-based safety device consists of Gear A, Gear B, a rotary damper, a bar, two tension springs, two pins, and two switches. Gear A is attached to Shaft D. The two tension springs are attached to the bar. The ends of the tension springs are connected to the tension spring brackets by two pins. Gear $\mathrm{B}$ is connected to the rotary damper and meshes with Gear A. The bar is connected to the shaft of the rotary damper. The two switches are attached to Bracket $\mathrm{D}$ via two switch brackets. The tension spring brackets are attached to Bracket $\mathrm{D}$. Bracket $\mathrm{D}$ is attached to Frame C. 

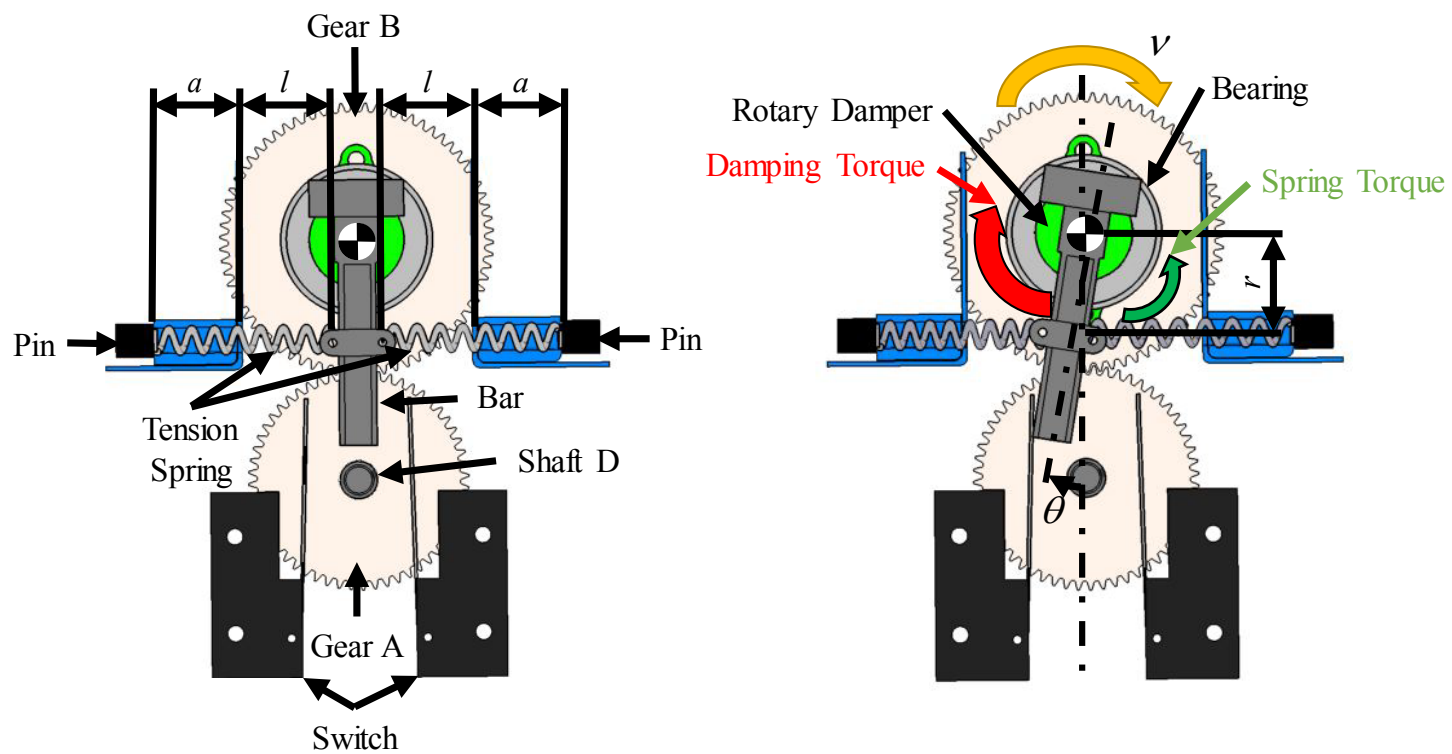

Fig. 5 Mechanism of the velocity-based safety device. When Gear B is rotated by the motor, the damping torque generated by the rotary damper and the spring torque generated by the tension springs act on the bar. If the angular velocity of Gear $\mathrm{B}$ exceeds a preset threshold level, the bar rotates by the torque difference between the damping and spring torques and switches off the motor. We call this preset threshold level the "detection velocity level". The detection velocity level is adjustable by changing the attachment positions of the switches.

\section{4. 設計・開発したアシストスーツ}

上記で提案したアシストスーツの具体的な設計を行う際に, 本研究ではその設計仕様を以下のように定めた. (1)本アシストスーツは，「人の脚をモータにより動か寸，いわゆるフルサポートのアシストスーツ」ではなく, 「人の脚の動きをモータによりアシストするアシストスーツ」とする．本研究では，その設計の一例として約 $8 \mathrm{Nm}$ まで患者の膝関節をサポートできるアシストスーツとする. また，トルクリミッタによる検知トルクレベ ルを $4 \mathrm{Nm}$ 設定可能とする.

(2)本アシストスーツは，健常者が歩行する際の膝関節の速度程度（文献(Perry and Burnfield, 2010)に掲載されて いる健常者の通常歩行時の膝関節のデータより約 $6 \mathrm{rad} / \mathrm{s}$ ) まで出力可能とし, 速度ベース安全装置による速度制 限はその速度まで設定変更可能とする.

以上を設計仕様として実際に設計・開発したアシストスーツの外観図を図 6 に示す．また，その主要部品を 表 1 に示寸. 表 1 より，モータの最大トルク $0.170 \mathrm{Nm}$ ，ギアヘッドの減速比 $26: 1$ ，トーションバネの許容最大 トルク $5.63 \mathrm{Nm}$ ，かさ歯車 A と B の減速比 2:1 であるので，摩擦の影響がなければ，本アシストスーツは膝関 節において $8.84 \mathrm{Nm}$ までトルクを出力することが可能である. また, 同表よりモータの最大連続卜ルク時の速度 は 7.26× $10^{2} \mathrm{rad} / \mathrm{s}$ であるので，膝関節（シャフト D）において約 $14 \mathrm{rad} / \mathrm{s}$ まで出力可能である．さらに，速度べ 一ス安全装置において, 図 7 に示すように, スイッチブラケットを移動（スライド）させ，ボルトとナットで 固定できる機構を製作し, 検知速度レベルを膝関節において 0 ～6.2 $\mathrm{rad} / \mathrm{s}$ まで設定変更ができるようにした. ト ルクリミッタには，検知トルクレベルを膝関節において $4 \mathrm{Nm}$ から $10 \mathrm{Nm}$ まで設定変更可能で, 設定した検知卜 ルクレベルを超えたトルクが作用すると動力伝達を遮断する MSK2-10Nm5-D-65-8×8-6Nm (R + W ANTRIEBSELEMENTE GMBH) を用いた．図 8 に示すように本トルクリミッタの調節リングを回すことにより 検知トルクレベルの設定変更が可能である. 


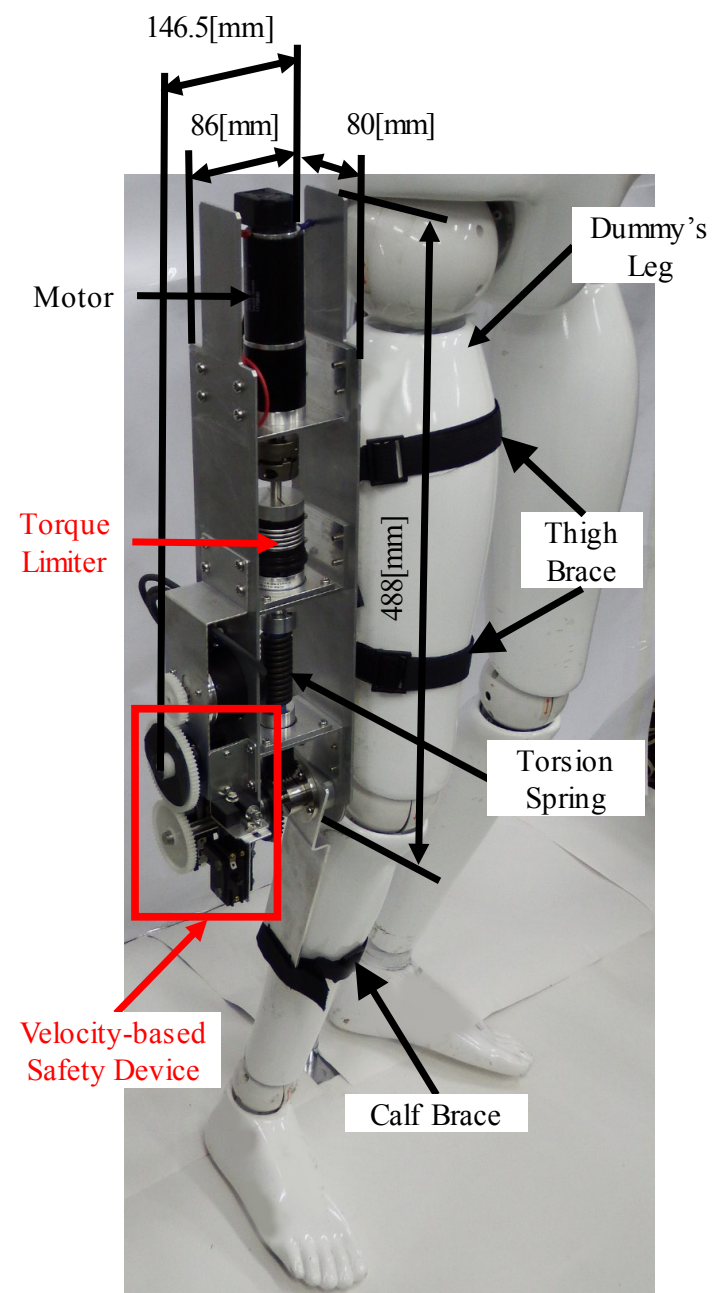

Fig. 6 Assist suit designed for assisting the knee joint. The assist suit is attached to a patient's leg with two thigh braces and one calf brace.
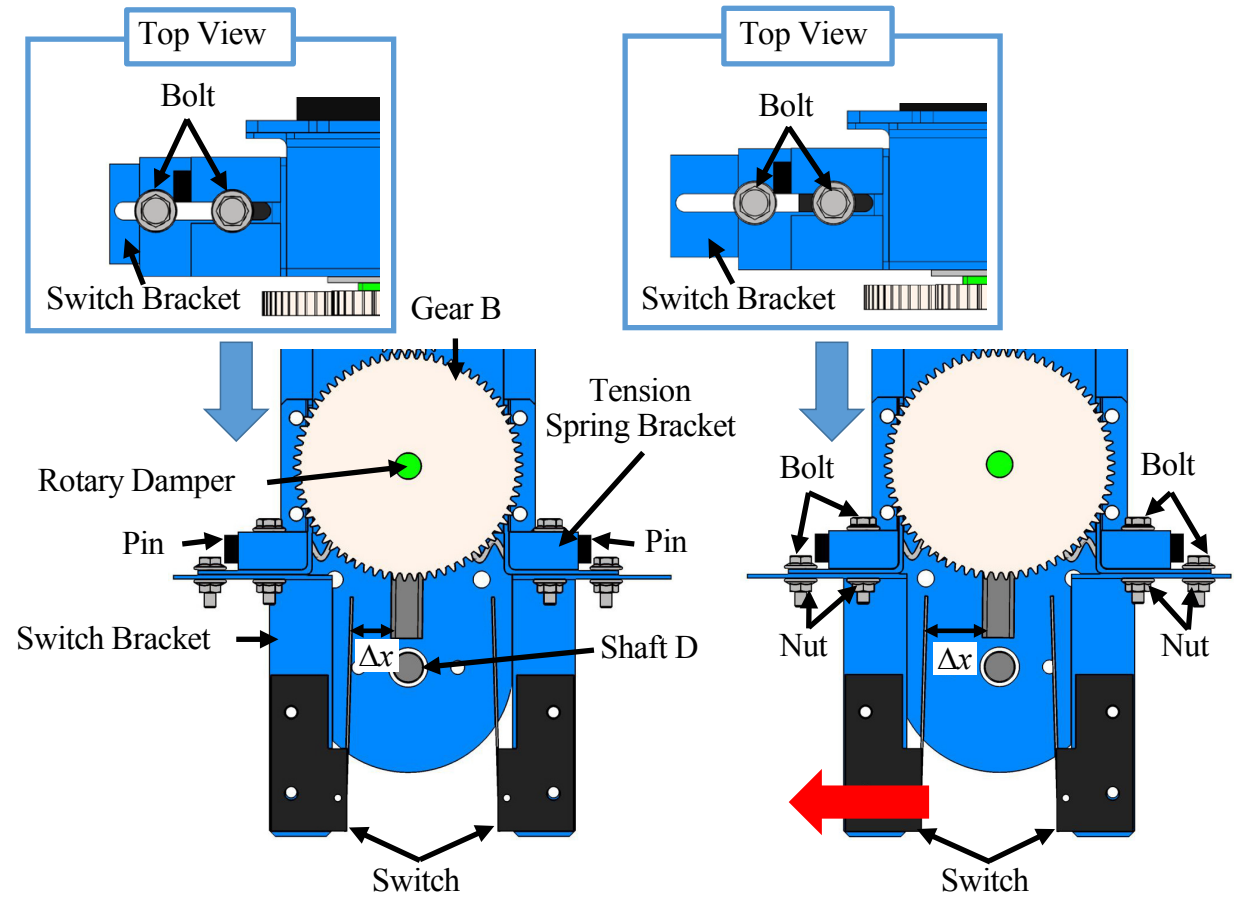

Fig. 7 Adjustment mechanism of the detection velocity level. The detection velocity level is adjustable by changing the attachment positions of the switch brackets (i.e. by moving the switch brackets and fixing it with the bolts and the nuts). 


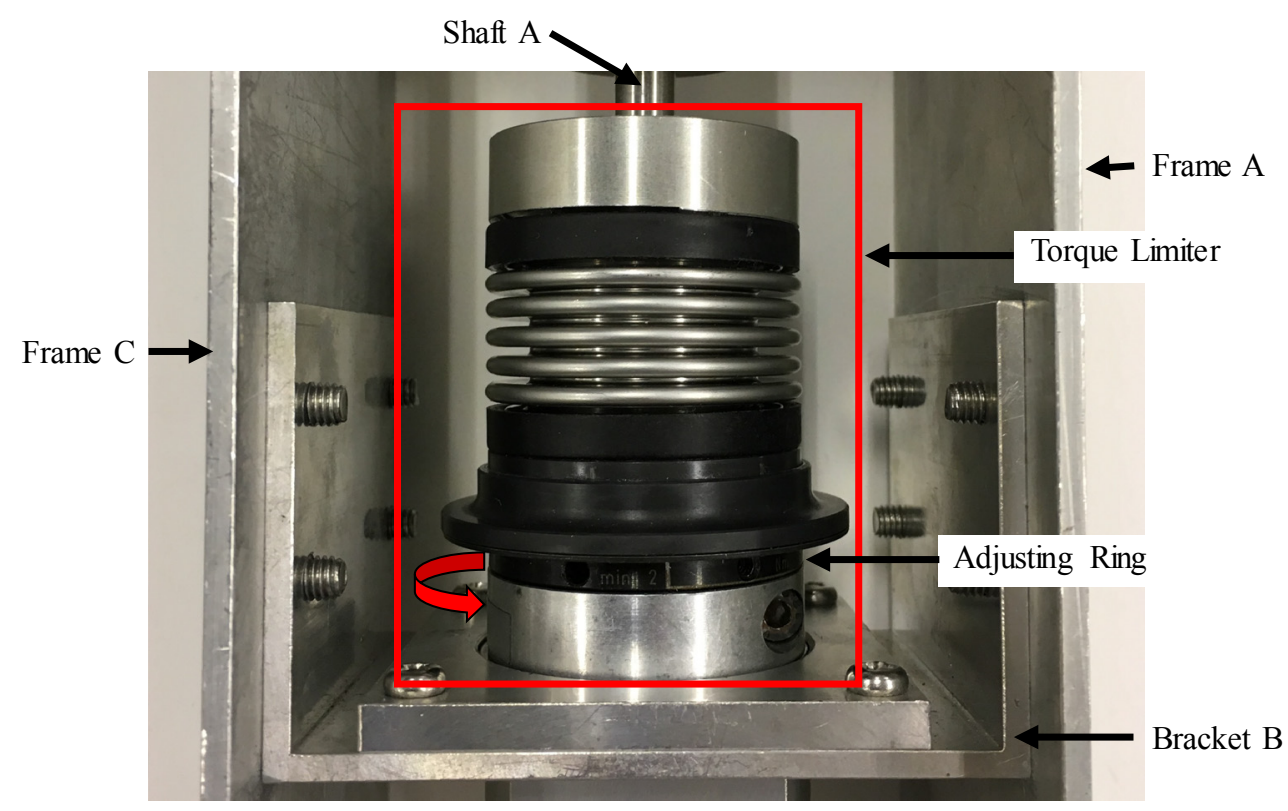

Fig. 8 Adjustment mechanism of the detection torque level. The detection torque level is adjustable by using the adjusting ring.

Table 1 Main parts

\begin{tabular}{|c|c|}
\hline Motor & RE40(MAXON MOTOR, Maximum Torque: $170 \mathrm{mNm}$, Nominal Speed: $6940 \mathrm{rpm}$ ) \\
\hline Gear Head & GP42C(MAXON MOTOR, Reduction:26:1) \\
\hline Bevel Gear A & SBS1.5-2040L(KOHARA GEAR INDUSTRY CO., LTD., Number of Teeth:20, Material: S45C) \\
\hline Bevel Gear B & SBS1.5-4020R(KOHARA GEAR INDUSTRY CO., LTD., Number of Teeth:40, Material: S45C) \\
\hline Torque Limiter & MSK2-10Nm5-D-65-8×8-6Nm (R + W ANTRIEBSELEMENTE GMBH) \\
\hline Torsion Spring & $\begin{array}{l}\text { TOKAIBANE MFG. CO., LTD., Maximum Deflection: } 90 \mathrm{deg} \text {, } \\
\text { Wire Diameter: } 4.0 \mathrm{~mm} \text {, Maximum Torque: } \pm 5.63 \mathrm{Nm} \text {, Mean Diameter of Spring: } 20 \mathrm{~mm} \text {, Number } \\
\text { of Turns: } 11.5 \text {, Spring Constant: } 62.5 \mathrm{Nmm} / \mathrm{deg}\end{array}$ \\
\hline Gear A & DS1-56(KOHARA GEAR INDUSTRY CO., LTD., Number of Teeth:56, Material:M90-44) \\
\hline Gear B & DS1-70(KOHARA GEAR INDUSTRY CO., LTD., Number of Teeth:70, Material:M90-44) \\
\hline Gear C & DS1-36(KOHARA GEAR INDUSTRY CO., LTD., Number of Teeth: 36, Material:M90-44) \\
\hline Rotary Damper & $\begin{array}{l}\text { TD62W1-1500(TOK BEARING CO., LTD., Damping Coefficient: } c=42.1 \times 10^{-3} \mathrm{Nms} / \mathrm{rad} \\
\text { (Measured Value)) }\end{array}$ \\
\hline Bar & $\begin{array}{l}\text { Mass : } 8.3 \mathrm{~g}, r=0.027 \mathrm{~mm}, \\
\text { The bar's center of gravity agrees with the shaft axis of the rotary damper. }\end{array}$ \\
\hline Tension Spring & HP080-039-1.0 (SHOWA SPRING CO., LTD., Spring Constant: $k=1.17 \times 10^{3} \mathrm{~N} / \mathrm{m}$ ) \\
\hline Switch & Z-15EWR (OMRON CO., LTD., $\left.\tau_{p}=0.029 \mathrm{Nm}\right)$ \\
\hline
\end{tabular}

\section{5. 実験}

アシストスーツに搭載した速度ベース安全装置が, 目的通り動作するか否か（すなわち，設定した検知速度 レベルを検知し，モータのスイッチを切るか否か）について実験により検証した，以下に，実験方法，実験結 果・考察を示す. 


\section{$5 \cdot 1$ 実験方法}

図 9 に本研究で用いた実験装置を示寸. 図 9 に示寸ように, 速度べース安全装置によりモータの電源が切ら れた時刻を計測するためにLED ランプを設置し，スイッチが押された際LED ランプが点灯するようにした. さらに，ギア B とバーにマーカーを取付け，開発したアシストスーツで実際に出力可能な最大加速度（ギア B における角速度 $v=18 t[\mathrm{rad} / \mathrm{s}]$ : 実験にて計測）で駆動させた。 この時のギア B の角速度，バーの角度変位，LED ランプの点灯時刻をモーションキャプチャシステム（k7-USB, KATO KOUKEN Corporation）により計測した. 検知速度レベルは式(2)を用いて設定した. 本実験では, 一例として, ギア B での角速度 $1.9 \mathrm{rad} / \mathrm{s}$ と 2.9rad/s（シ ヤフト D，すなわち膝関節の角速度に換算すると約 $2.4 \mathrm{rad} / \mathrm{s}$ と $3.6 \mathrm{rad} / \mathrm{s})$ に設定した. 各検知速度レベルで 20 回ずつ行った，モーションキャプチャシステムのサンプリング周波数は $200 \mathrm{~Hz}$ とした．なお，本実験において はアシストスーツのフレーム B を取り外して実験を行った。

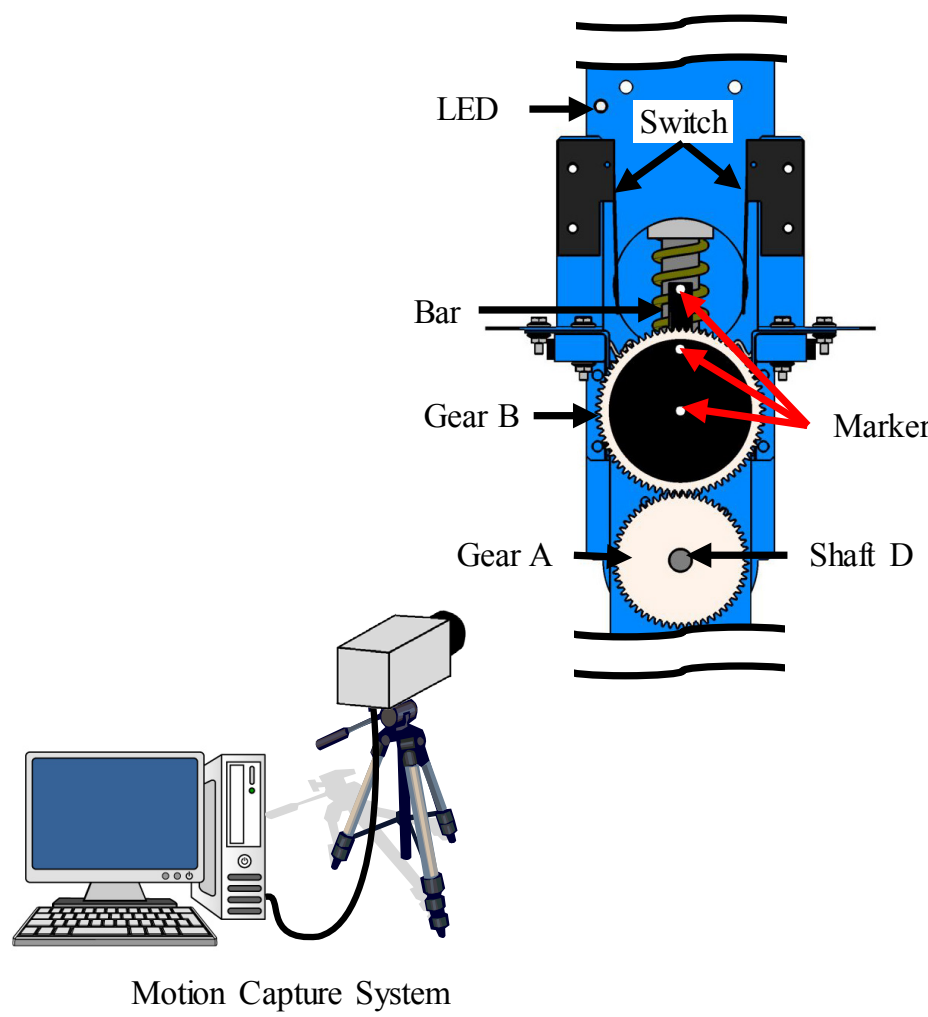

Fig. 9 Experimental setup. Three markers were attached to Gear B and the bar. The motion of the bar and the velocity of Gear B were both measured by using a motion capture system (k7-USB, KATO KOUKEN Corporation) while increasing the motor velocity.

\section{$5 \cdot 2$ 実験結果 $\cdot$ 考察}

各検知速度レベルにおける実験結果の代表例を図 10，図 11 に示寸. 各図において，横軸に時刻，縦軸にギア B の角速度を取り, バーがモータの電源を切った時刻（LED ライトが点灯した時刻）を青線で示している. 図 10 および図 11 より, バーがモータのスイッチをオフにした時, ギア B の角速度がほぼ検知速度レベルになっ ていることが確認できる.ささらに，その後，ギア B は減速し始め，最終的にギア B（すなわち，シャフト D) が停止していることがわかる. なお, 代表例以外の他の実験結果も同様の結果であった. 表 2 に, 各検知速度 レベルの実験において，バーがスイッチをオフにした時刻のギア B の角速度の平均值と標準偏差を示す.

図 10，図 11 および表 2 から，ギア B の角速度がほぼ設定した検知速度レベルに達したとき，速度べース安 全装置のバーによりスイッチが切られており, 速度ベース安全装置はほぼ目的通り動作していると考えられる. 設定した検知速度レベルと実験結果（電源が切られた時の角速度）の誤差は，使用しているロータリーダンパ の出力誤差, 引張バネの出力誤差, ギアのバックラッシュなどが原因であると考えられる. 
さらに, 図 10 および図 11 より, 本アシストスーツは速度ベース安全装置がモータのスイッチを切った後, 急停止するのではなく，惰性で動いた後停止していることがわかる．このことから，下肢の慣性程度でバック ドライブできることが推察されるが，本アシストスーツのバックドライブ性に関しては今後詳細に検討する予 定である.

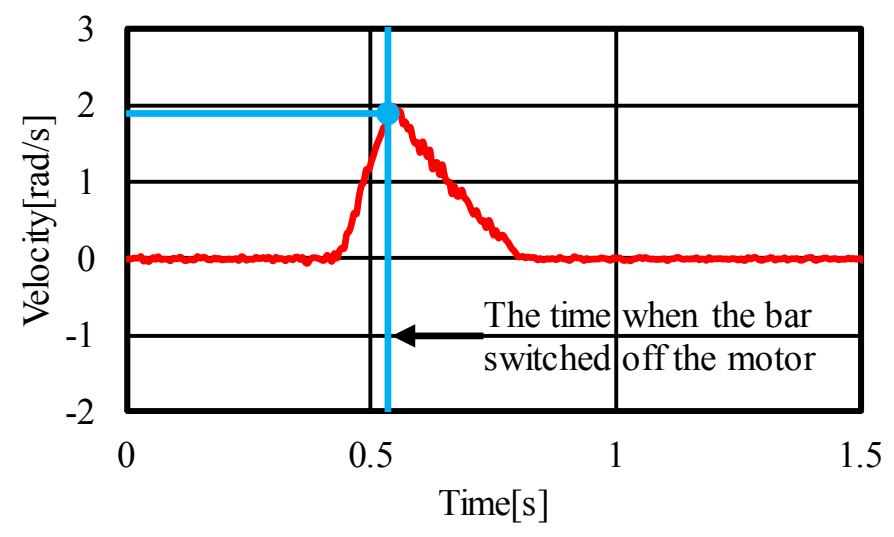

Fig. 10 Experimental result for the detection velocity level of $1.9 \mathrm{rad} / \mathrm{s}$.

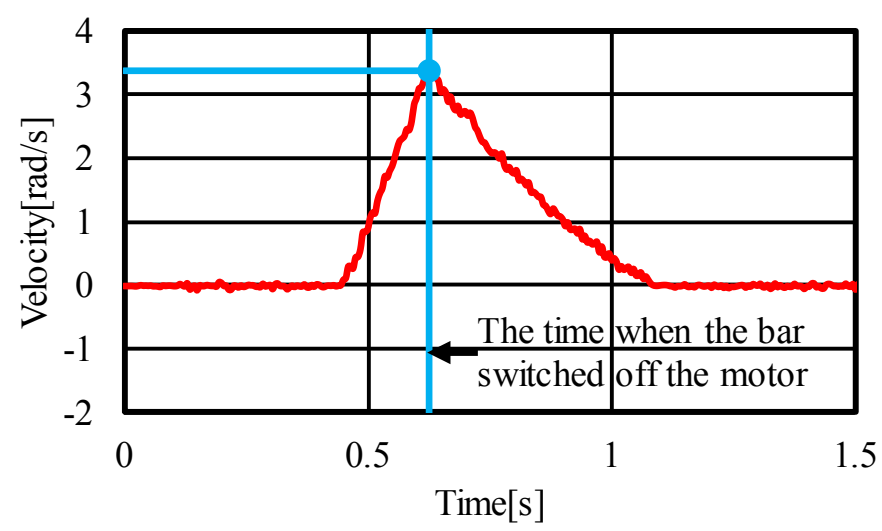

Fig. 11 Experimental result for the detection velocity level of $2.9 \mathrm{rad} / \mathrm{s}$.

Table 2 Experimental result (Average value \& Standard deviation)

\begin{tabular}{|c|c|c|}
\hline $\begin{array}{c}\text { Detection Velocity Level } \\
{[\mathrm{rad} / \mathrm{s}]}\end{array}$ & $\begin{array}{c}\text { Average Value } \\
{[\mathrm{rad} / \mathrm{s}]}\end{array}$ & $\begin{array}{c}\text { Standard Deviation } \\
{[\mathrm{rad} / \mathrm{s}]}\end{array}$ \\
\hline 1.9 & 1.9 & 0.1 \\
\hline 2.9 & 3.3 & 0.2 \\
\hline
\end{tabular}

\section{6. 結}

本論文では，アシストスーツの安全性向上を目指し，ハードウェアベース安全装置（速度ベース安全装置・ 市販のトルクリミッタ）を搭載した膝関節用アシストスーツを提案した．まず，提案したアシストスーツの特 徵について説明した. 次に, アシストスーツの構造, 速度ベース安全装置の構造・メカニズムについて述べた. さらに, 実際に設計・開発したアシストスーツを示した. 最後に, 本研究オリジナルの速度ベース安全装置が 目的通り動作するか否かについて，実験を行うことにより検証した．その結果，速度ベース安全装置は目的通 り動作していることが確認できた．本アシストスーツに “関節可動域を制限する関節リミッタ”や“スイッチ 部等に過電流が流れることを防止するためのヒューズ”などの安全対策を加えることにより，さらに安全なア シストスーツの開発が可能であると考えられる. 
今後は，アシストスーツの制御方法の検討や人の歩行時の周期的な運動に対して速度ベース安全装置が誤動 作を起こさないか等についての検討を行う，また，本速度べース安全装置においては，患者の歩行状態（立脚 期・遊脚期や屈曲・伸展時）によらず患者の関節に予期せ女高速度が発生するとモー夕の電源を切るように設 計したが, 電源を切った後の患者の転倒, 本アシストスーツのバックドライブ性なども含めその有効性を, 患 者吊上げ装置を併用した実験等を行うことにより，検討する予定である．さらに，下肢全体をアシストするア シストスーツの設計・開発を行う予定である.

\section{謝辞}

本研究の一部は JSPS 科研費 $15 \mathrm{~K} 05910$ の助成により行われた.

\section{文献}

Bae, J., Kong, K. and Tomizuka, M., Control algorithms for prevention of impacts in rehabilitation systems, Proceedings of the 2011 International Conference on Advanced Intelligent Mechatronics (AIM2011) (2011), pp.128-133.

Chen, F., Yu, Y., Ge, Y., Sun, J. and Deng, X., A PAWL for enhancing strength and endurance during walking using interaction force and dynamical information, Climbing and Walking Robots: towards New Applications (2007), pp.417-428.

Cherelle, P., Grosu, V., Beyl, P., Mathys, A., Ham, R. V., Damme, M. V., Vanderborght, B. and Lefeber, D., The MACCEPA actuation system as torque actuator in the gait rehabilitation robot ALTACRO, Proceedings of the 2010 3rd IEEE RAS \& EMBS International Conference on Biomedical Robotics and Biomechatronics (2010), pp.27-32.

長谷川真人，山海嘉之，ロボットスーツ HALR 福祉用を用いた歩行練習の効果 : 慢性不全脊髄損傷者に対する症 例研究, 理学療法科学, 29-1 (2014), pp.151-156.

医療情報科学研究所編, 病気が見える vol. 7 脳・神経 第 1 版 (2011), pp.168-257, メディックメディア.

Kai, Y., Development of a Walking Support Machine with a Lift Device Controlled by a Servo Brake, Proceedings of the SICE Annual Conference 2013 (SICE 2013) (2013), pp.1728-1733.

Kawamoto, H., Lee, S., Kanbe, S. and Sankai, Y., Power assist method for HAL-3 using EMG-based feedback controller, Proceedings of the 2003 International Conference on Systems, Man and Cybernetics (SMC2003) (2003), pp.1648-1653.

Kong, K., Bae, J. and Tomizuka, M., A compact rotary series elastic actuator for human assistive systems, IEEE/ASME Transactions on Mechatronics, Vol. 17, No. 2 (2012), pp. 288-297.

Perry, J. and Burnfield, J. M., Gait analysis: normal and pathological function (Second edition) (2010), pp. 85-534, SLACK Incorporated.

Riener, R., Technology of the robotic gait orthosis Lokomat, Neurorehabilitation Technology (2012), pp.221-232.

園田茂編, 動画で学ぶ脳卒中のリハビリテーション(2005), pp.6-73, 医学書院.

United Nations Population Fund (UNFPA) and HelpAge International, Ageing in the Twenty-First Century: A Celebration and A Challenge (2013), pp.19-26, United Nations Population Fund and HelpAge International.

Westlake, K. P. and Patten, C., Pilot study of Lokomat versus manual-assisted treadmill training for locomotor recovery post-stroke, Journal of NeuroEngineering and Rehabilitation (2009), 6:18.

Zhang, W., Zhu, X., Han, S., Byl, N., Mok, A. K. and Tomizuka, M., Design of a network-based mobile gait rehabilitation system, Proceedings of the IEEE International Conference on Robotics and Biomimetics (2012), pp.1773-1778.

\section{References}

Bae, J., Kong, K. and Tomizuka, M., Control algorithms for prevention of impacts in rehabilitation systems, Proceedings of the 2011 International Conference on Advanced Intelligent Mechatronics (AIM2011) (2011), pp.128-133.

Chen, F., Yu, Y., Ge, Y., Sun, J. and Deng, X., A PAWL for enhancing strength and endurance during walking using interaction force and dynamical information, Climbing and Walking Robots: towards New Applications (2007), pp.417-428.

Cherelle, P., Grosu, V., Beyl, P., Mathys, A., Ham, R. V., Damme, M. V., Vanderborght, B. and Lefeber, D., The MACCEPA actuation system as torque actuator in the gait rehabilitation robot ALTACRO, Proceedings of the 2010 3rd IEEE RAS \& EMBS International Conference on Biomedical Robotics and Biomechatronics (2010), pp.27-32.

Hasegawa, M. and Sankai, Y., Gait Training with the Robot Suit HAL Well-being Type for a Man with Incomplete Spinal 
Cord Injury, The Society of Physical Therapy Science, 29-1 (2014), pp.151-156 (in Japanese).

Institute for Health Care Information Sciences ed., Medical Disease: An Illustrated Reference Guide $<$ vol. $7>$ Neurology and Neurosurgery 1st Edition (2011), pp.168-257, Medic Media (in Japanese).

Kai, Y., Development of a Walking Support Machine with a Lift Device Controlled by a Servo Brake, Proceedings of the SICE Annual Conference 2013 (SICE 2013) (2013), pp.1728-1733.

Kawamoto, H., Lee, S., Kanbe, S. and Sankai, Y., Power assist method for HAL-3 using EMG-based feedback controller, Proceedings of the 2003 International Conference on Systems, Man and Cybernetics (SMC2003) (2003), pp.1648-1653.

Kong, K., Bae, J. and Tomizuka, M., A compact rotary series elastic actuator for human assistive systems, IEEE/ASME Transactions on Mechatronics, Vol. 17, No. 2 (2012), pp. 288-297.

Perry, J. and Burnfield, J. M., Gait analysis: normal and pathological function (Second edition) (2010), pp. 85-534, SLACK Incorporated.

Riener, R., Technology of the robotic gait orthosis Lokomat, Neurorehabilitation Technology (2012), pp.221-232.

Sonoda, S. ed., Douga De Manabu Nousottyuu No Rihabiriteishon (2005), pp. 6-73, Igakushoin (in Japanese).

United Nations Population Fund (UNFPA) and HelpAge International, Ageing in the Twenty-First Century: A Celebration and A Challenge (2013), pp.19-26, United Nations Population Fund and HelpAge International.

Westlake, K. P. and Patten, C., Pilot study of Lokomat versus manual-assisted treadmill training for locomotor recovery post-stroke, Journal of NeuroEngineering and Rehabilitation (2009), 6:18.

Zhang, W., Zhu, X., Han, S., Byl, N., Mok, A. K. and Tomizuka, M., Design of a network-based mobile gait rehabilitation system, Proceedings of the IEEE International Conference on Robotics and Biomimetics (2012), pp.1773-1778. 